\title{
Identification of Molecular Markers Linked to Leaf Rust Resistance Genes in Wheat and Their Detection in the Local Near-Isogenic Line
}

\author{
Navjot Kaur Dhillon $^{1^{*}}$, Harcharan Singh Dhaliwal ${ }^{2}$ \\ ${ }^{1}$ Department of Plant Breeding and Genetics, Punjab Agricultural University, Ludhiana, India; ${ }^{2}$ Akal School of Biotechnology, Baru \\ Sahib, Himachal Pradesh, India. \\ Email: *dhillon.navjot@gmail.com
}

Received May $31^{\text {st }}, 2011$; revised July 20 ${ }^{\text {th }}, 2011$; accepted August $7^{\text {th }}, 2011$.

\begin{abstract}
Sixty-five random amplified polymorphic DNA (RAPD) primers were used for the detection of polymorphism among recipient and donor parents and their isogenic lines linked to leaf rust resistance genes, Lr9 and the resistant gene in kharchia local mutant KLM4-3B. Three primers showed polymorphism among recurrent parent, donor parent and isogenic lines.
\end{abstract}

Keywords: RAPD, Lr9, Isogenic Lines

\section{Introduction}

With the introduction of semi-dwarf, photoinsensitive, fertilizer responsive and the high yielding varieties of wheat, the wheat production in India has increased from 12 million tonnes in 1966 to 70 million tonnes in the recent years. Wheat exceeds every other grain crop in acreage and production and is, therefore, the most important cereal of the world. It is imperative to stabilize the wheat production by reducing the losses due to various diseases including leaf rust, stem rust, yellow rust, Karnal bunt etc. Among the diseases, leaf rust caused by Puccinia recondita Roberage ex. Desmaz f.sp. tritici is one of the most important and devastating foliar diseases of wheat which cause significant yield losses all over the world [1-5]. Breeding for resistance against leaf rust is an economical, efficient and environmentally safe control measure to reduce these losses. Development of disease resistant varieties is one of the most economical methods of control of diseases like leaf rust. However, growing of rust resistant varieties having single gene for resistance results in rapid evolution of virulent biotypes of the pathogen, thereby making the resistance gene ineffective and the variety susceptible to rust. It is difficult to pyramid two or more disease resistance genes through conventional means, particularly where the resistance genes in question are effective against all the prevalent pathotypes. However, recent advances in molecular biology has made it possible to pyramid several genes in single line using marker assisted selection (MAS) and tagging of genes with molecular markers is pre-requisite for MAS.

A number of rust resistance genes, including leaf rust, have been transferred from wild relatives of wheat into cultivated wheats [6]. Most of which could not be exploited because of extensive linkage drag. One of the leaf rust resistance genes, Lr9 transferred from Aegilops umbellulata [7] and located on chromosome 6BL, has no undesirable effect associated with it [8]. This gene is effective against all the races of leaf rust currently prevalent in northern India. Similarly, another leaf rust resistance gene identified in (Kharchia local mutantKLM4-3B) is also effective against all the prevalent leaf rust pathotypes in northern India.

Keeping this in view the present study was undertaken to identify molecular markers linked with $\operatorname{Lr} 9$ and KLM4-3B and to pyramid $\operatorname{Lr} 9$ with rust resistant gene in KLM4-3B, as both the genes provide resistance against most of the leaf rust pathotypes of the Indian subcontinent.

\section{Materials and Methods}

\subsection{Plant Material}

Near-isogenic lines carrying the leaf rust resistance genes $L r 9$ and the $L r$ gene of KLM4-3B in the background of 
WL711 developed at the School of Biotechnology were used along with the donor and the recurrent parents for identifying RAPD markers linked to the two genes.

\subsection{Genomic DNA Isolation}

Approximately $5 \mathrm{~g}$ fresh weight of young leaves were harvested from plants grown in the field and DNA was extracted as per the method of Dellaporta [9].

\subsection{Random Amplified Polymorphic DNA (RAPD) Analysis}

RAPD analysis was carried out as described by Williams [10] using 10 base pair (bp) primers from Operon Technologies Inc., Alameda, California. PCR was performed in a reaction volume of $25 \mu \mathrm{l}$, containing $2.5 \mu \mathrm{l}$ of $1 \mathrm{mM}$ dNTPs, $3.2 \mu \mathrm{l}$ of $15 \mathrm{mM} \mathrm{MgCl}_{2}, 2.5 \mu \mathrm{l}$ of $10 \mathrm{X}$ buffer containing $10 \mathrm{mM}$ tris- $\mathrm{HCl} \mathrm{pH} 8.3,2.0 \mathrm{mM} \mathrm{MgC1} 1_{2}, 50$ $\mathrm{mM} \mathrm{KC1}, 1.5 \mu \mathrm{l}(20 \mathrm{ng})$ of single 10-base primer, $1 \mu \mathrm{l}$ $(30 \mathrm{ng})$ of template DNA and $0.5 \mu \mathrm{l}$ (1 unit) of Taq polymerase (Stratagene). The reaction mixture was topped with $50 \mu$ of sterilized mineral oil. Template DNA was initially denatured at $94^{\circ} \mathrm{C}$ for 5 minutes followed by 45 cycles of PCR amplification under following parameters. One minute denaturation at $94^{\circ} \mathrm{C}$, one minute primer annealing at $36^{\circ} \mathrm{C}$ and 2 minutes primer extension at $72^{\circ} \mathrm{C}$ further followed by 5 minutes final extension at $72^{\circ} \mathrm{C}$ on a Perkin Elmer Cetus Thermal Cycler.

\subsection{Gel Electrophoresis and Photography}

$5 \mu$ loading buffer consisting of $0.5 \%$ bromophenol blue,
$0.5 \%$ xylene cynole $\mathrm{FF}$ and $50 \%$ glycerol in 1XTAE buffer (0.04M Tris-acetate, $0.001 \mathrm{M}$ EDTA) was added to the PCR amplification products for visualization of gel run. Aliquots of $25 \mu \mathrm{l}$ of DNA products from the PCR amplification were loaded in $1.5 \%$ agarose gel prepared in $1 \times$ TAE buffer at $3 \mathrm{~V} / \mathrm{cm}$. Gel was stained with ethidium bromide and photographed under UV light.

\section{Results and Discussion}

In the present investigation, to identify molecular markers linked with $\operatorname{Lr} 9$ and KLM4-3B and to pyramid $\operatorname{Lr} 9$ with rust resistant gene in KLM4-3B, RAPD markers were tried on near-isogenic lines carrying the leaf rust resistance genes $L r 9$ and the $L r$ gene of KLM4-3B in the background of WL711 along the recipient and donor parents of the isogenic lines for the two genes in WL711. The results pertaining to these studies are presented here.

\subsection{RAPD Analysis}

65 random primers were tried to study polymorphism among recurrent and donor parents and their isogenic line (Table 1). Out of 65 primers tested, 42 primers gave amplification (64.62\%). Total number of loci amplified with 42 primers tested in WL711, KLM4-3B, isogenic line of $L r$ KLM4-3B, Thatcher $+L r 9$ and isogenic line of Lr9 were 148, 145, 140, 126 and 126, respectively. Limited polymorphism was detected among WL 711, Thatcher + Lr9, WL $711+L r 9, L r$ KLM4-3B, WL $711+L r$ KLM4-3B when genomic DNA was amplified with the RAPD primers.

Table 1. Number of RAPD loci in recurrent parent, donor parent and isogenic lines.

\begin{tabular}{|c|c|c|c|c|c|c|}
\hline \multirow{2}{*}{ Primer Primer } & \multirow{2}{*}{$\begin{array}{l}\text { Sequence of the } \\
\text { primer } \\
5^{\prime} \text { to } 3^{\prime}\end{array}$} & \multicolumn{5}{|c|}{ Number of RAPD loci } \\
\hline & & WL 711 & KLM 4-3B & WL711 + KLM4-3B & Thatcher + Lr9 & WL711 + Lr9 \\
\hline OPA-02 & TGCCGAGCTC & 3 & 3 & 3 & 3 & 3 \\
\hline OPA-14 & TCTGTGCTGG & 2 & 1 & 1 & 1 & 1 \\
\hline OPA-15 & TTCCGAACCC & 2 & 2 & 2 & 2 & 2 \\
\hline OPA-16 & AGCCAGCGAA & 2 & 2 & 2 & 3 & 3 \\
\hline OPA-18 & AGGTGACCGT & 3 & 3 & 3 & 2 & 2 \\
\hline OPA-19 & CAAACGTCGG & 2 & 3 & 2 & 1 & 1 \\
\hline OPB-05 & TGCGCCCTTC & 5 & 5 & 5 & 5 & 5 \\
\hline OPB-06 & TGCTCTGCCC & 3 & 3 & 3 & 3 & 3 \\
\hline OPB-15 & GGAGGGTGTT & 6 & 3 & 3 & 3 & 3 \\
\hline OPB-17 & AGGGAACGAG & 5 & 3 & 3 & 3 & 3 \\
\hline OPC-02 & GTGAGGCGTC & 2 & 2 & 2 & 2 & 2 \\
\hline OPC-04 & CCGCATCTAC & - & 2 & - & - & - \\
\hline OPC-16 & CACACTCCAG & 2 & 3 & 5 & 5 & 3 \\
\hline OPC-20 & ACTTCGCCAC & 5 & 5 & 5 & 3 & 5 \\
\hline OPD-12 & CACCGTATCC & 3 & 1 & 3 & 3 & 4 \\
\hline OPD-14 & CTTCCCCAAG & 2 & 2 & 2 & - & - \\
\hline
\end{tabular}



Their Detection in the Local Near-Isogenic Line

\begin{tabular}{|c|c|c|c|c|c|c|}
\hline \multirow{2}{*}{ Primer Primer } & \multirow{2}{*}{$\begin{array}{l}\text { Sequence of the primer } \\
5^{\prime} \text { to } 3^{\prime}\end{array}$} & \multicolumn{5}{|c|}{ Number of RAPD loci } \\
\hline & & WL 711 & KLM 4-3B & WL711 + KLM4-3B & Thatcher $+\operatorname{Lr} 9$ & WL711 + Lr9 \\
\hline OPE-10 & CACCAGGTGA & 1 & - & - & - & - \\
\hline OPE-20 & AACGGTGACC & 4 & 4 & 2 & 4 & 4 \\
\hline OPG-13 & CTCTCCGCCA & 3 & 3 & 3 & 3 & 3 \\
\hline OPG-14 & GGATGAGACC & 4 & 4 & 4 & 4 & 4 \\
\hline OPG-17 & ACGACCBACA & 2 & 2 & 2 & 2 & 2 \\
\hline OPJ-01 & CCCGGCATAA & 6 & 6 & 6 & 6 & 6 \\
\hline OPJ-05 & CTCCATGGGG & 1 & 1 & 1 & - & - \\
\hline OPJ-10 & AAGCCCGAGG & 7 & 6 & 6 & 7 & 7 \\
\hline OPJ-12 & GTCCCGTGGT & 2 & 2 & 2 & 2 & 2 \\
\hline OPK-10 & GTGCAACGTG & 10 & 10 & 10 & 10 & 10 \\
\hline OPK-13 & GGTTGTACCC & 1 & 1 & 1 & 1 & 1 \\
\hline OPK-15 & CTCCTGCCAA & 3 & - & - & - & - \\
\hline OPK-16 & GAGCGTCGAA & 3 & 3 & 3 & 3 & 3 \\
\hline OPO-10 & TCAGAGCGCC & 4 & 4 & 4 & 3 & 3 \\
\hline OPO-11 & GACAGGAGGT & 1 & 1 & 1 & 1 & 1 \\
\hline OPP-01 & GTAGCACTCC & 6 & 6 & 6 & 6 & 6 \\
\hline OPP-05 & CCCCGGTAAC & 4 & 4 & 4 & - & - \\
\hline OPP-06 & GTGGGCTGAC & 4 & 4 & 4 & 2 & 2 \\
\hline OPP-10 & TCCCGCCTAC & 5 & 5 & 5 & 3 & 3 \\
\hline OPP-19 & GGCTTGGCCT & 6 & 6 & 6 & 6 & 6 \\
\hline OPZ-12 & TCAACGGGAC & 3 & 3 & 3 & 3 & 3 \\
\hline OPZ-15 & CAGGGCTTTC & 1 & 1 & 1 & 1 & 1 \\
\hline OPZ-17 & ССТTCССАCT & 5 & 5 & 5 & 5 & 5 \\
\hline OPBA-06 & ATATTTGGCC & 4 & 4 & 4 & 3 & 3 \\
\hline OPBA-12 & GCCCTTAGCA & 3 & 3 & 3 & 2 & 2 \\
\hline OPBA-14 & GCAATGGGAT & 3 & 3 & 3 & 3 & 3 \\
\hline Total Number of Loci & 148 & 145 & 140 & 126 & 126 & \\
\hline
\end{tabular}


Some genes of agronomic importance, however, have been tagged with RAPD markers in tomato $[11,12]$, in rice [13-15], and in wheat [16-19]. The three primers (OPA-19, OPD-12, OPJ-10) were polymorphic between WL711 and other stocks. One RAPD locus amplified with primer OPA-19 was observed in Thatcher $+\operatorname{Lr} 9$ and its isogenic lines. The amplification product was absent in WL711 (Figure 1). This indicated association of this RAPD marker with Lr9.

Similarly, with RAPD primer OPD-12, one locus was specifically amplified in KLM4-3B and the isogenic line carrying Lr KLM4-3B. The amplification product was absent in WL711 (Figure 2).

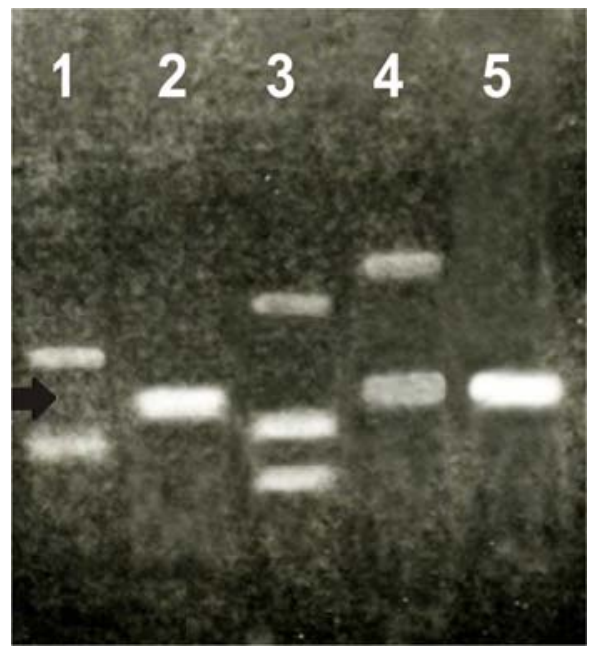

Figure 1. Genomic DNA amplification with primer OPA-19. Lane1: WL711; lane2: Lr9; lane3: KLM4-3B; lane4: WL711 + KLM4-3B; lane5: WL711 + Lr9.

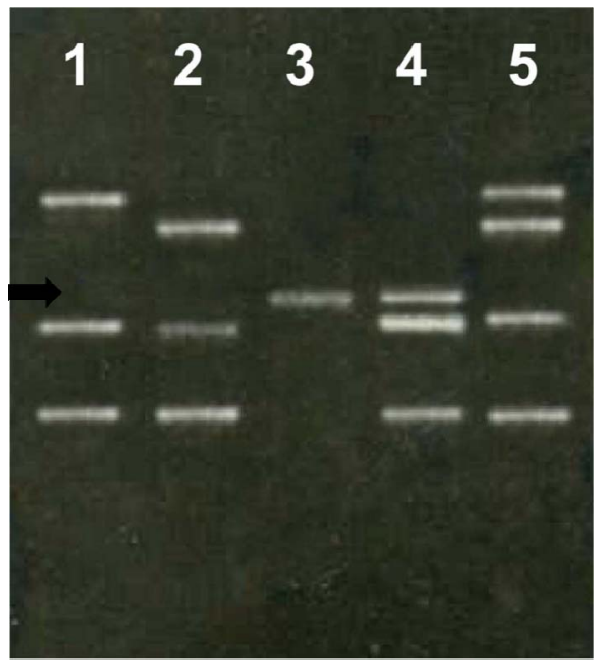

Figure 2. Genomic DNA amplification with primer OPD-12. Lane1: WL711; lane2: Lr9; lane3: KLM4-3B; lane4: W1711 + KLM4-3B; lane5: WL711 + Lr9.
Amplification of a distinct RAPD loci associated with Lr9 with RAPD, primer OPA-19 and its absence in donor and isogenic lines containing LrKLM4-3B vs RAPD primer OPD-12 which amplified a distinct loci associated with LrKLM4-3B and absent in lines with $\operatorname{Lr} 9$ further indicate that $L r 9$ and $L r K L M 4-3 \mathrm{~B}$ are non-allelic.

Bread wheat has a narrow genetic base. This was also shown by limited polymorphism for many molecular markers $[20,21]$. This limited polymorphism along with higher ploidy level and high repetitive DNA content has impeded genetic linkage mapping in wheat. RAPD markers behave as dominant markers because polymorphism is detected as the presence/absence of bands. RAPD markers provide a quick and cost effective method for generating genetic maps and analyzing population. MAS could be useful in the development of highly resistant germplasm based on new combinations of $L r$ genes are Lr53 [22], Lr56 [23], Lr57 [24], Lr59 [25], Lr62 [26], Lr63 and Lr66 [27].

\section{REFERENCES}

[1] M. G. Eversmeyer and L. E. Browder, "Effect of Leaf and Stem Rust on 1973 Kansaswheat Yields," Plant Disease Reporter, Vol. 58, No. 5, 1974, pp. 469-471.

[2] R. G. Saini and A K Gupta, "Genes for Resistance to Brown Rust Puccinia recondita) in Wheat. II. Lr Genes in Frontana, WG138 and E6360," Cereal Research Communications, Vol. 7, 1979, pp. 289-291.

[3] D. Anand, R. G. Saini and A. K. Gupta, "Slow Leaf Rust Development Due to Combination of Some Genes in Wheat," Plant Disease Reporter, Vol. 3, 1988, p. 97.

[4] M. Seck, A. P. Roelfs and P. S. Teng, "Effect of Leaf Rust Puccinia recondite triticii on Yield of Four Isogenic Wheat Lines," Crop Production, Vol. 7, No. 1, 1988, pp. 39-43. doi:10.1016/0261-2194(88)90036-1

[5] K. V. Subha Rao, J. P. Snow and G. T. Berggren, "Effect or Growth Stage and Initial Inoculum Level on Leaf Rust Development and Yield Loss Caused by Puccinia recondita f. sp. tritici," Journal of Phytopathology, Vol. 127, No. 3, 1989, pp. 200-210. doi:10.1111/j.1439-0434.1989.tb01130.x

[6] M. Baum, E. S. Laguadah and R. Appels, "Wide Crosses in Cereals," Annual Review of Plant Physiology and Plant Molecular Biology, Vol. 43, 1992, pp. 117-143. doi:10.1146/annurev.pp.43.060192.001001

[7] E. R. Sears, "The Transfer of Leaf Rust Resistance from Aegilops umbellulata into Wheat," Brookhaven Symposia in Biology, Vol. 9, 1956, pp. 1-21.

[8] A. S. Soliman, E. Y. Heyne and C. O. Johnston, "Resistance to Leaf Rust in Wheat Derived from Chinese Aegilops umbellulata Translocation Lines," Crop Science, Vol. 3, No. 3, 1963, pp. 254-256. doi:10.2135/cropsci1963.0011183X000300030025x

[9] S. L. Dellaporta, J. Wood and J. B. Hicks, “A Plant DNA 
Mini Preparation. Version 11," Plant Molecular Biology Reporter, Vol. 1, No. 4, 1983, pp. 19-21. doi:10.1007/BF02712670

[10] J. G. K. Williams, A. R. Kubelik, K. J. Livak, J. A. Rafulski and S. V. Tingey, “ DNA Polymorphisms Amplified by Arbitrary Primers Are Useful Genetic Marker," Nucleic Acids Research, Vol. 18, No. 22, 1990, pp. 65316535. doi:10.1093/nar/18.22.6531

[11] G. B. Martin, J. G. K. Williams and S. D. Tanksley, "Rapid Identification of Markers Linked to a Pseudomonas Resistance Gene in Tomato by Using Random Primers and Near Isogenic Lines," Proceedings of the $\mathrm{Na}$ tional Academy of Sciences of the USA, Vol. 88, No. 6, 1991, pp. 2236-2340. doi:10.1073/pnas.88.6.2336

[12] L. R. M. Klein, A. Vermunt, R. Weide, T. Liharska and R. Zabel, "Isolation of Molecular Markers for Tomato ( $L$. esculentum) Using Random Amplified Polymorphic DNA (RAPD)," Theoretische und Angewandte Genetik, Vol. 83, No. 1, 1991, pp. 108-114.

[13] P. C. Ronald, B. Albano, R. Tabien, L. Abenes, K. S. Wu, S. McCouch and S. D. Tanskley, "Genetic and Physical Analysis of the Rice Bacterial Blight Disease Resistance Locus, Xa21," Molecular \& General Genetics, Vol. 236, No. 1, 1992, pp. 113-120.

[14] S. Yoshimura, A. Yoshimura, N. Iwata, S. R. McCouch, M. L. Abenes, M. R. Baraoiden, T. W. Mew and K. J. Nelson, "Tagging and Combining Bacterial Blight Resistance Genes in Rice Using RAPD and RFLP Markers," Molecular Breeding, Vol. 1, No. 4, 1995, pp. 375-387.

[15] S. Yoshimura, A. Yoshimura, R. J. Nelson, T. W. Mew and N. Iwata, "Tagging $\mathrm{Xa}-\mathrm{l}$ the Bacterial Blight Resistant Gene in Rice, by Using RAPD Markers," Breed Science, Vol. 45, 1995, pp. 81-85.

[16] I. Dweikat, H. Ohm, S. MacKenzie, F. Patterson, S. Cambron and R. Rateliffe, "Association of a DNA Marker with Hessian Fly Resistance Gene H9 in Wheat," Theoretical and Applied Genetics, Vol. 89, No. 7-8, 1994, pp. 964-968. doi:10.1007/BF00224525

[17] J. D. Procunier, T. F. Townley Smith, S. Fox, S. Prashar, M. Gray, W. K. Kim, Czarnecki and P. L. Dyck, "PCRBased RAPD/DGGE Markers Linked to Leaf Rust Resistance Genes Lr29 and Lr25 in Wheat (T. aestivum)," Journal of Genetics and Breeding, Vol. 49, No. 1, 1995, pp. 87-91.

[18] G. Schachermayr, M. Messmer, C. Feuillet, H. Winzeler, M. Winzeler and B. Keller, "Identification of Molecular Markers Linked to the Agropyron elongatum-Derived Leaf Rust Resistance Gene Lr24 in Wheat," Theoretical and Applied Genetics, Vol. 90, No. 7-8, 1995, pp. 982990. doi:10.1007/BF00222911

[19] L. E. Talbert, P. L. Bruckner, L. Y. Smith, R. Sears and T. J. Martin, "Development of PCR Markers Linked to Resistance to Wheat Streak Mosaic Virus in Wheat," Theoretical and Applied Genetics, Vol. 93, No. 3, 1996, pp. 463-467. doi:10.1007/BF00223191

[20] S. Chao, J. Sharp, A. J. Worland, E. J. Warham, R. Koebner and M. D. Gale, "RFLP-Based Genetic Maps of Wheat Homoeologous Group 7 Chromosomes," Theoretical and Applied Genetics, Vol. 78, No. 4, 1998, pp. 495-504. doi:10.1007/BF00290833

[21] L. N. W. Kam-Morgan, B. S. Gill and S. Muthukrishan, "DNA Restriction Fragment Length Polymorphisms: A Strategy for Genetic Mapping of D-Genome of Wheat," Genome, Vol. 32, No. 4, 1989, pp. 724-732.

[22] N. A. Dadkhodaie, H. Karaoglou, C. R. Wellings and R. F. Park, "Mapping Genes Lr53 and Yr35 on the Short Arm of Chromosome 6B of Common Wheat with Microsatellite Markers and Studies of Their Association with Lr36," Theoretical and Applied Genetics, Vol. 122, No. 3, 2010, pp. 479-487. doi:10.1007/s00122-010-1462-y

[23] G. F. Marais, P. E. Badenhorst, A. Eksteen and Z. A. Pretorius, "Reduction of Aegilops sharonensis Chromatin Associated with Resistance Genes Lr56 and Yr38 in Wheat," Euphytica, Vol. 171, No. 1, 2010, pp. 15-22.

[24] V. Kuraparthy, S. Sood, D. R. See and B. S. Gill, "Development of a PCR Assay and Marker-Assisted Transfer of Leaf Rust and Stripe Rust Resistance Genes Lr57 and Yr40 into Hard Red Winter Wheats," Crop Science, Vol. 49, No. 1, 2009, pp. 120-126. doi:10.2135/cropsci2008.03.0143

[25] G. F. Marais, B. Mccallum and A. S. Marais, "Wheat Leaf Rust Resistance Gene Lr59 Derived from Aegilops peregrin," Plant Breeding, Vol. 127, No. 4, 2008, pp. 340-345. doi:10.1111/j.1439-0523.2008.01513.x

[26] F. Marais, A. Marais, B. Mccallum and Z. Pretorius, "Transfer of Leaf Rust and Stripe Rust Resistance Genes Lr62 and Yr42 from Aegilops neglecta Req. ex Bertol. to Common Wheat," Crop Science, Vol. 49, No. 3, 2009, pp. 871-879. doi:10.2135/cropsci2008.06.0317

[27] G. F. Marais, T. A. Bekker, A. Eksteen, B. Mccallum, T. Fetch and A. S. Marais, "Attempts to Remove Gametocidal Genes Co-Transferred to Common Wheat with Rust Resistance from Aegilops speltoides," Euphytica, Vol. 171, No. 1, 2010, pp. 71-85. 